\title{
Mutations in the m-AAA proteases AFG3L2 and SPG7 are causing isolated dominant optic atrophy
}

\author{
Majida Charif, PhD, Arnaud Chevrollier, PhD, Naïg Gueguen, PhD, Céline Bris, PhD, David Goudenège, PhD, \\ Valérie Desquiret-Dumas, PhD, Stéphanie Leruez, MD, Estelle Colin, MD, PhD, Audrey Meunier, MD, \\ Catherine Vignal, MD, PhD, Vasily Smirnov, MD, Sabine Defoort-Dhellemmes, MD, \\ Isabelle Drumare Bouvet, MD, Cyril Goizet, MD, PhD, Marcela Votruba, MD, PhD, Neringa Jurkute, MD, PhD, \\ Patrick Yu-Wai-Man, MD, PhD, Francesca Tagliavini, PhD, Leonardo Caporali, PhD, Chiara La Morgia, MD, PhD, \\ Valerio Carelli, MD, PhD, Vincent Procaccio, MD, PhD, Xavier Zanlonghi, MD, Isabelle Meunier, MD, PhD, \\ Pascal Reynier, MD, PhD, Dominique Bonneau, MD, PhD, Patrizia Amati-Bonneau, MD, PhD, and \\ Guy Lenaers, PhD
}

Neurol Genet 2020;6:e428. doi:10.1212/NXG.0000000000000428

\section{Abstract \\ Objective}

To improve the genetic diagnosis of dominant optic atrophy (DOA), the most frequently inherited optic nerve disease, and infer genotype-phenotype correlations.

\section{Methods}

Exonic sequences of 22 genes were screened by new-generation sequencing in patients with DOA who were investigated for ophthalmology, neurology, and brain MRI.

\section{Results}

We identified 7 and 8 new heterozygous pathogenic variants in SPG7 and AFG3L2. Both genes encode for mitochondrial matricial AAA (m-AAA) proteases, initially involved in recessive hereditary spastic paraplegia type 7 (HSP7) and dominant spinocerebellar ataxia 28 (SCA28), respectively. Notably, variants in AFG3L2 that result in DOA are located in different domains to those reported in SCA28, which likely explains the lack of clinical overlap between these 2 phenotypic manifestations. In comparison, the SPG7 variants identified in DOA are interspersed among those responsible for HSP7 in which optic neuropathy has previously been reported.

\section{Conclusions}

Our results position SPG7 and AFG3L2 as candidate genes to be screened in DOA and indicate that regulation of mitochondrial protein homeostasis and maturation by m-AAA proteases are crucial for the maintenance of optic nerve physiology.

\author{
Correspondence \\ Dr. Lenaers \\ guy.lenaers@inserm.fr
}




\section{Glossary}

DOA = dominant optic atrophy; HSP7 = hereditary spastic paraplegia; OCT = optical coherence tomography; RGC = retinal ganglion cell; RNFL = retinal nerve fiber layer; SCA28 = spinocerebellar ataxia.

Dominant optic atrophy (DOA, MIM*605290) is the most commonly inherited optic neuropathy, leading to irreversible loss of retinal ganglion cells (RGCs), optic nerve degeneration, and central visual loss. ${ }^{1,2}$ More than 400 OPA1 variants were identified in DOA individuals, ${ }^{3-6}$ resulting in excess of mitochondrial fission. ${ }^{7,8}$ Surprisingly, a similar clinical presentation was also reported in individuals with dominant DNM1L mutations 9 (MIM603850) and mitochondrial network hyperfusion, thus providing evidence that alterations of both fusion and fission compromise RGC survival. This hypothesis was further supported by the identification in syndromic DOA families of dominant mutations in MFN2 (MIM608507) ${ }^{10}$ and OPA3 (MIM606580), ${ }^{11} 2$ additional genes acting on mitochondrial dynamics. More recently, a single SPG7 (MIM602783) mutation and a single AFG3L2 (MIM604581) mutation were reported in DOA families, ${ }^{12-14}$ although mutations in these genes are commonly known to be responsible for the recessive hereditary spastic paraplegia type 7 $(\mathrm{HSP} 7)^{15}$ and dominant spinocerebellar ataxia 28 (SCA28), ${ }^{16}$ respectively. In addition, the occurrence of heterozygous variants in SPG7 and AFG3L2 was identified in a patient affected with DOA and parkinsonism, ${ }^{17}$ a clinical presentation found in few patients with OPA1. ${ }^{18}$ SPG7 and AFG3L2 are paralogue genes encoding mitochondrial matricial AAA (m-AAA)proteases involved in protein homeostasis and the cleavage of the OMA1 and YME1L mitochondrial proteases, which control the shift between profusion long and profission short OPA1 isoforms. ${ }^{19}$

This prompted us to screen SPG7 and AFG3L2 exonic sequences in patients with DOA without molecular diagnosis. We report the identification of pathogenic variants in these 2 genes in nonsyndromic patients with DOA.

\section{Methods}

\section{Standard protocol approvals, registrations, and patient consents}

Written informed consent to perform genetic analyses was obtained from each subject involved in this study or from the parents of individuals younger than 18 years of age, according to the protocols approved by the ethical committees of the different institutes involved in this study and in agreement with the Declaration of Helsinki (Institutional Review Board Committee of the University Hospital of Angers, Authorization number: AC-2012-1507).

\section{Genetic analysis}

Genomic DNA was extracted from peripheral blood cells from multinational cohorts of DOA and sporadic cases of optic atrophy, initially screened for OPA1, OPA3, and WFS1 exonic sequences and the 3 primary Leber hereditary optic neuropathy mutations. Cases negative after this primary screening were analyzed by resequencing a panel of 22 genes (table e-1, links.lww.com/NXG/A260) involved in inherited optic neuropathies or in mitochondrial dynamics. Library preparation for each sample was performed using an Ion AmpliSeq Library Kit 2.0 (Cat. no. 4480441) according to the manufacturer's protocol (Thermo Fisher Scientific, MAN0006735). Sample emulsion PCR, emulsion breaking, and enrichment were performed using the Ion $540 \mathrm{Kit}-\mathrm{Chef}$ (Cat. no. A27759) according to the manufacturer's instructions (Thermo Fisher Scientific, MAN0010851). Sequencing was performed using a $540 \mathrm{ChIPs}$ on an Ion S5 Sequencer using the barcoded samples. Sequencing data were processed using our own dedicated bioinformatics pipeline, as described elsewhere. ${ }^{20}$ Candidate pathogenic variants were validated by Sanger sequencing, and their segregation was assessed in DNAs from other members of the families, when available.

\section{Cell studies}

Fibroblasts from AFG3L2 individuals P1: III: 2 and P2: II: 1 from family 9 and 15, respectively, were generated from skin biopsies and cultured in 2/3 Dulbecco's Minimum Essential Medium (DMEM, Gibco) supplemented with 1/3 AmnioMAX (Gibco), $10 \%$ fetal calf serum (Lonza), and 1\% Penicillin-StreptomycinAmphotericin B (Lonza). Mitochondrial network analysis, respiratory chain enzymatic activities, and mtDNA copy number were assessed as described. ${ }^{9}$

\section{Data availability}

All data relevant to this study are contained within the article.

\section{Results}

\section{Identification of SPG7 and AFG3L2 pathogenic variants in individuals with DOA or isolated optic atrophy using a targeted sequencing panel}

Six hundred cases without positive result after screening $O P A 1, O P A 3$, and WFS1 exonic sequences and the 3 primary Leber hereditary optic neuropathy mutations were included in a resequencing program focused on 22 genes, among which were those already firmly established for DOA and recessive optic atrophy and candidate genes encoding actors of the mitochondrial dynamics. After eliminating frequent $(>1 / 10.000)$ and nonpathogenic variants, according to the SIFT, PolyPhen, MutationTaster, and LRT prediction tools, we identified 7 and 8 individuals harboring a SPG7 or an 


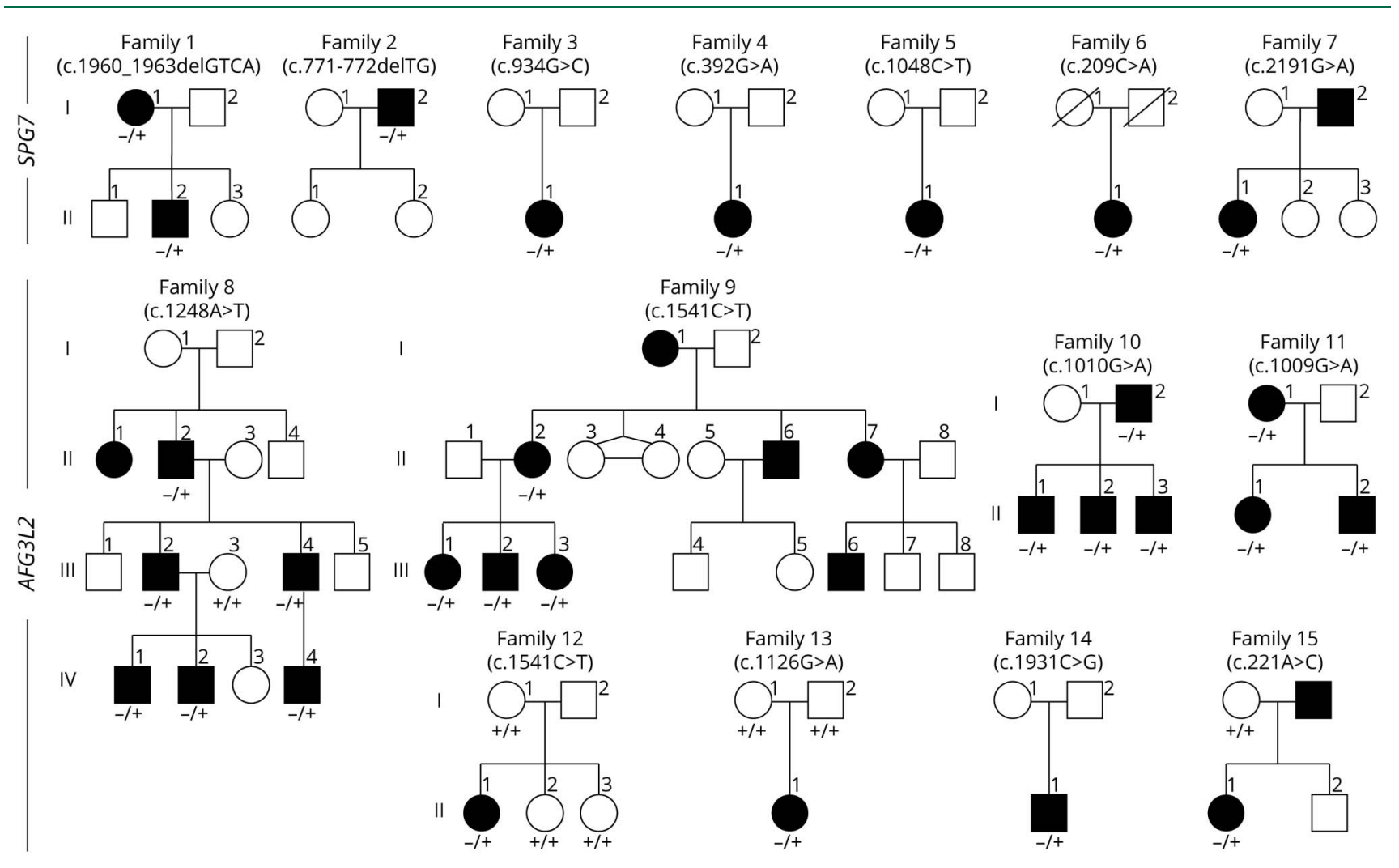

Description of the pedigrees with SPG7 (top) and AFG3L2 (middle and bottom) mutations and their segregation among the DOA families. DOA = dominant optic atrophy.

AFG3L2 pathogenic heterozygous variant, respectively. These variants were confirmed by Sanger sequencing and analyzed for segregation whenever possible in the respective families. Segregation of the 15 variants fitted with the clinical features of affected individuals for whom DNA samples were available (Figure 1). In family 13, the c.1126G > A variant in $A F G 3 L 2$ was not found in both parents, suggesting that it occurred de novo.

\section{Phenotypic manifestations of SPG7 and AFG3L2 mutation carriers}

All individuals included were referred to ophthalmology departments for visual acuity impairment. At inclusion, none of them complained of spastic paraplegia or SCA, and in all cases but one, the brain MRI was normal. All patients with SPG7 presented optic disk pallor and accordingly, reduced retinal nerve fiber layer (RNFL) at optical coherence tomography (OCT) scanning, mainly on the temporal side (figure 2A). Nevertheless, their visual acuity alterations were mild, with scores ranging from $3 / 10$ to $10 / 10$ (table 1) and occurring during midlife for all individuals except one (family 3, II-1). Patient II.1 from family 4 with the best visual acuity only presented a significant reduction of the RNFL at the OCT examination. No additional symptom was observed for the index cases and their relatives when the clinical data were available, except for a hearing impairment in family 5 (table 1).
Conversely, all AFG3L2 mutated individuals disclosed a severe optic atrophy with visual acuities ranging from $0.2 / 10$ to $2 / 10$, except for the 3 members of family 7 who had visual acuity scores above 4/10 (table 1). First ophthalmologic examination occurred in a broad range of age, with some individuals being affected early during the first 2 decades, as reported for patients with $O P A 1 .^{1}$ All patients disclosed optic nerve pallor and highly reduced RNFL at OCT scanning (figure 2B). Similar to SPG7, no brain MRI abnormality was reported in investigated patients, except for patient II.1 from family 14, who had a pituitary adenoma without cerebellar atrophy. This individual had a hearing impairment in addition to a very low visual acuity (table 1).

\section{Functional consequences of SPG7 and AFG3L2 mutations}

SPG7 and AFG3L2 encode highly similar proteins with 5 conserved domains (figure 3). Four of the DOA mutations in SPG7 are referenced with a frequency close to $1 \mathrm{e}-05$ in the GnomAD database, whereas the 3 others were not referenced. All SPG7 variants responsible for DOA are interspersed with the recessive variants responsible for HSP7, and 2 of them are deletions leading to a frameshift at positions 258 and 654 . These latter data suggest that SPG7 haploinsufficiency might be the primary causal pathologic process in DOA. Surprisingly, other heterozygote composite frameshift mutations were 

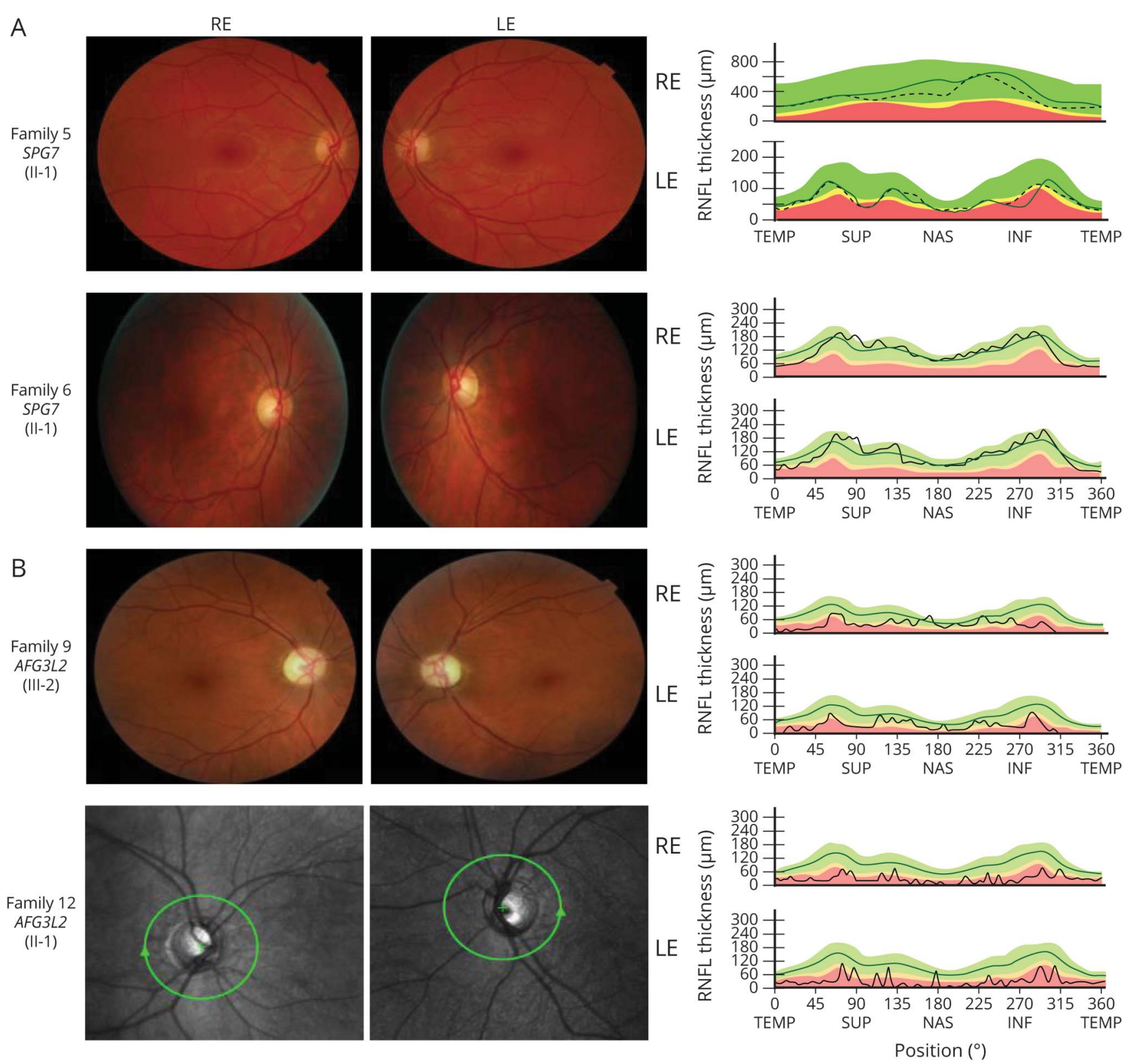

Left: Eye fundus pictures of individuals with SPG7 (A, family 5, II.1 and family 6 II.1) and individuals with AFG3L2 (B, family 9, III:2 and family 12, II.1) revealing the temporal pallor of the optic discs in both REs and LEs. Right: RNFL by optic coherence tomography in individuals, disclosing the mild reduction of RNFL thickness in the individuals with SPG7 (A) and the severe one in the individuals with $A F G 3 L 2(B)$. The green area defines the 5 th to 95 th, the yellow area the $1 \mathrm{st}$ to 5th, and the red area below the 1st percentiles. INF = inferior quadrants; LE = left eye; NAS = nasal; RE = right eye; RNFL = retinal nerve fiber layer assessment; SUP = superior; TEMP = temporal.

reported to cause $\mathrm{HSP} 7$, even at an earlier position toward the $\mathrm{N}$-end of the protein (figure $3 \mathrm{~A}$ ). Unfortunately, no individual with a $S P G 7$ variant accepted to provide a skin biopsy to infer fibroblasts for functional validation.

Seven out of the $8 A F G 3 L 2$ variants identified in this study were not referenced in any database. They result in missense amino acid changes (table 1), and all but one (p.Thr644Ser from family 14) are located in domains different from the one involved in SCA28 individuals, suggesting that they affect another AFG3L2 function than the one responsible for the SCA28 phenotype (figure 3B). Two fibroblast cell lines were established from individuals III: 2 from family 9 and II: 1 from family 15 to assess their mitochondrial shape and physiology. A tendency toward mitochondrial fragmentation was observed in $A F G 3 L 2$ fibroblasts (figure e-1, links.lww. com/NXG/A261), together with a significant reduction of $\mathrm{CI}, \mathrm{CIII}$, and CIV enzymatic activities, which correlated with a significant citrate synthase decreased activity, suggesting a reduction of the mitochondrial mass. This prompted the analysis of mitochondrial DNA copy number (figure e-1), which showed a significant $50 \%$ reduction in $A F G 3 L 2$ cells. 
Table 1 Clinical data of the patients with SPG7 and AFG3L2

\begin{tabular}{|c|c|c|c|c|c|c|c|c|c|c|c|}
\hline Family & Patient & Sex & Age & VA & $\begin{array}{l}\text { Other } \\
\text { symptoms }\end{array}$ & Brain MRI & Gene & $\begin{array}{l}\text { ORF } \\
\text { mutation }\end{array}$ & Protein change & rs \# & $\begin{array}{l}\text { GnomAD } \\
\text { Freq. }\end{array}$ \\
\hline 1 & I.1 & $\mathrm{F}$ & 42 & $4 / 10$ & - & Normal & SPG7 & $\begin{array}{l}\text { c.1960- } \\
\text { 1963delGTCA }\end{array}$ & p.Val654Profs*7 & Unknown & \\
\hline 2 & II.1 & M & 43 & $3 / 10$ & $\begin{array}{l}\text { Liver } \\
\text { cirrhosis }\end{array}$ & ND & SPG7 & $\begin{array}{l}\text { c.773- } \\
\text { 774delTG }\end{array}$ & p.Val258Glyfs*30 & rs768136171 & 8.03e-06 \\
\hline 3 & II.1 & $\mathrm{F}$ & 8 & $5 / 10$ & - & Normal & SPG7 & c. $934 \mathrm{G}>\mathrm{C}$ & p.Ala312Pro & Unknown & \\
\hline 4 & II.1 & $\mathrm{F}$ & 66 & $\begin{array}{l}10 / \\
10\end{array}$ & - & Normal & SPG7 & c. $392 \mathrm{G}>\mathrm{A}$ & p.Arg131His & rs985921704 & $7.99 \mathrm{e}-06$ \\
\hline 5 & II.1 & $\mathrm{F}$ & 31 & $9 / 10$ & $\begin{array}{l}\text { Hearing } \\
\text { impairment }\end{array}$ & ND & SPG7 & c. $1048 C>T$ & p.Pro350Ser & rs199789849 & 2 e-05 \\
\hline 6 & II.1 & $\mathrm{F}$ & 64 & $5 / 10$ & - & Normal & SPG7 & c. $209 C>A$ & p.Pro70His & Unknown & \\
\hline 7 & II.1 & $\mathrm{F}$ & 62 & $\begin{array}{l}2 \& 9 / \\
10\end{array}$ & - & Normal & SPG7 & c. $2191 \mathrm{G}>\mathrm{A}$ & p.Ala731Thr & rs747521455 & $3.19 e-5$ \\
\hline \multirow[t]{3}{*}{8} & 111.2 & M & 36 & $5 / 10$ & - & Normal & AFG3L2 & c. $1248 \mathrm{~A}>\mathrm{T}$ & p.Arg416Ser & Unknown & \\
\hline & IV.1 & M & 7 & $5 / 10$ & - & Normal & AFG3L2 & c. $1248 \mathrm{~A}>\mathrm{T}$ & p.Arg416Ser & & \\
\hline & IV.4 & M & 8 & $4 / 10$ & - & Normal & $A F G 3 L 2$ & c. $1248 \mathrm{~A}>\mathrm{T}$ & p.Arg416Ser & & \\
\hline \multirow[t]{4}{*}{9} & 11.2 & $\mathrm{~F}$ & 47 & $2 / 10$ & - & Normal & AFG3L2 & c. $1541 C>T$ & p.Pro514Leu & Unknown & \\
\hline & III.1 & $\mathrm{F}$ & 26 & $1 / 10$ & - & Normal & $A F G 3 L 2$ & c. $1541 C>T$ & p.Pro514Leu & & \\
\hline & III.2 & M & 22 & $1 / 10$ & - & Normal & $A F G 3 L 2$ & c. $1541 C>T$ & p.Pro514Leu & & \\
\hline & 111.3 & $\mathrm{~F}$ & 15 & $1 / 10$ & - & Normal & $A F G 3 L 2$ & c. $1541 C>T$ & p.Pro514Leu & & \\
\hline \multirow[t]{4}{*}{10} & 1.2 & M & 80 & $1 / 10$ & - & ND & $A F G 3 L 2$ & c. $1010 \mathrm{G}>\mathrm{A}$ & p.Gly337Glu & Unknown & \\
\hline & II.1 & $M$ & 61 & $\begin{array}{l}1.6 / \\
10\end{array}$ & - & ND & $A F G 3 L 2$ & c. $1010 \mathrm{G}>\mathrm{A}$ & p.Gly337Glu & & \\
\hline & 11.2 & $M$ & 60 & $\begin{array}{l}1.6 / \\
10\end{array}$ & - & ND & $A F G 3 L 2$ & c. $1010 \mathrm{G}>\mathrm{A}$ & p.Gly337Glu & & \\
\hline & 11.3 & $\mathrm{M}$ & 58 & $\begin{array}{l}1.6 / \\
10\end{array}$ & - & ND & AFG3L2 & c. $1010 \mathrm{G}>\mathrm{A}$ & p.Gly337Glu & & \\
\hline \multirow[t]{3}{*}{11} & I.1 & $\mathrm{F}$ & 46 & $\begin{array}{l}0.5 / \\
10\end{array}$ & - & Normal & $A F G 3 L 2$ & c. $1009 \mathrm{G}>\mathrm{A}$ & p.Gly337Arg & Unknown & \\
\hline & II.1 & $\mathrm{F}$ & 13 & $\begin{array}{l}0.5 / \\
10\end{array}$ & - & Normal & $A F G 3 L 2$ & c. $1009 \mathrm{G}>\mathrm{A}$ & p.Gly337Arg & & \\
\hline & 11.2 & $M$ & 7 & $\begin{array}{l}0.8 / \\
10\end{array}$ & - & Normal & $A F G 3 L 2$ & c. $1009 \mathrm{G}>\mathrm{A}$ & p.Gly337Arg & & \\
\hline 12 & II.1 & $\mathrm{F}$ & 25 & $\begin{array}{l}0.21 \\
10\end{array}$ & - & Normal & $A F G 3 L 2$ & c. $1541 C>T$ & p.Pro514Leu & Unknown & \\
\hline 13 & II.1 & $\mathrm{F}$ & 9 & $\begin{array}{l}1.3 / \\
10\end{array}$ & - & Normal & $A F G 3 L 2$ & c. $1126 \mathrm{G}>\mathrm{A}$ & p.Glu376Lys & Unknown & \\
\hline 14 & II.1 & $M$ & 59 & $\begin{array}{l}1.6 / \\
10\end{array}$ & - & Normal & AFG3L2 & c.1931C>G & p.Thr644Ser & rs1226952405 & $3.98 \mathrm{e}-06$ \\
\hline 15 & II.1 & $\mathrm{F}$ & 19 & $\begin{array}{l}0.5 / \\
10\end{array}$ & $\begin{array}{l}\text { Hearing } \\
\text { impairment }\end{array}$ & $\begin{array}{l}\text { Pituitary } \\
\text { adenomas }\end{array}$ & AFG3L2 & c. $221 \mathrm{~A}>\mathrm{C}$ & p.Glu74Ala & Unknown & \\
\hline
\end{tabular}

Abbreviations: GnomAD Freq. = frequency in the genome aggregation database; ND = not done; ORF = open reading frame; rs \# = reference sequence number; $V A=$ visual acuity.

\section{Discussion}

Dominant SPG7 and AFG3L2 mutations can result in isolated optic nerve involvement with a clinical phenotype indistinguishable from that seen in patients with DOA harboring dominant OPA1 mutations. As in OPA1-positive DOA, SPG7 and AFG3L2 mutation carriers can present with a broad spectrum of visual impairment ranging from asymptomatic 
Figure 3 Structural representation of SPG7 and AFG3L2 amino acid changes related to mutations in individuals with DOA, HSP7, and SCA28/SPAX5
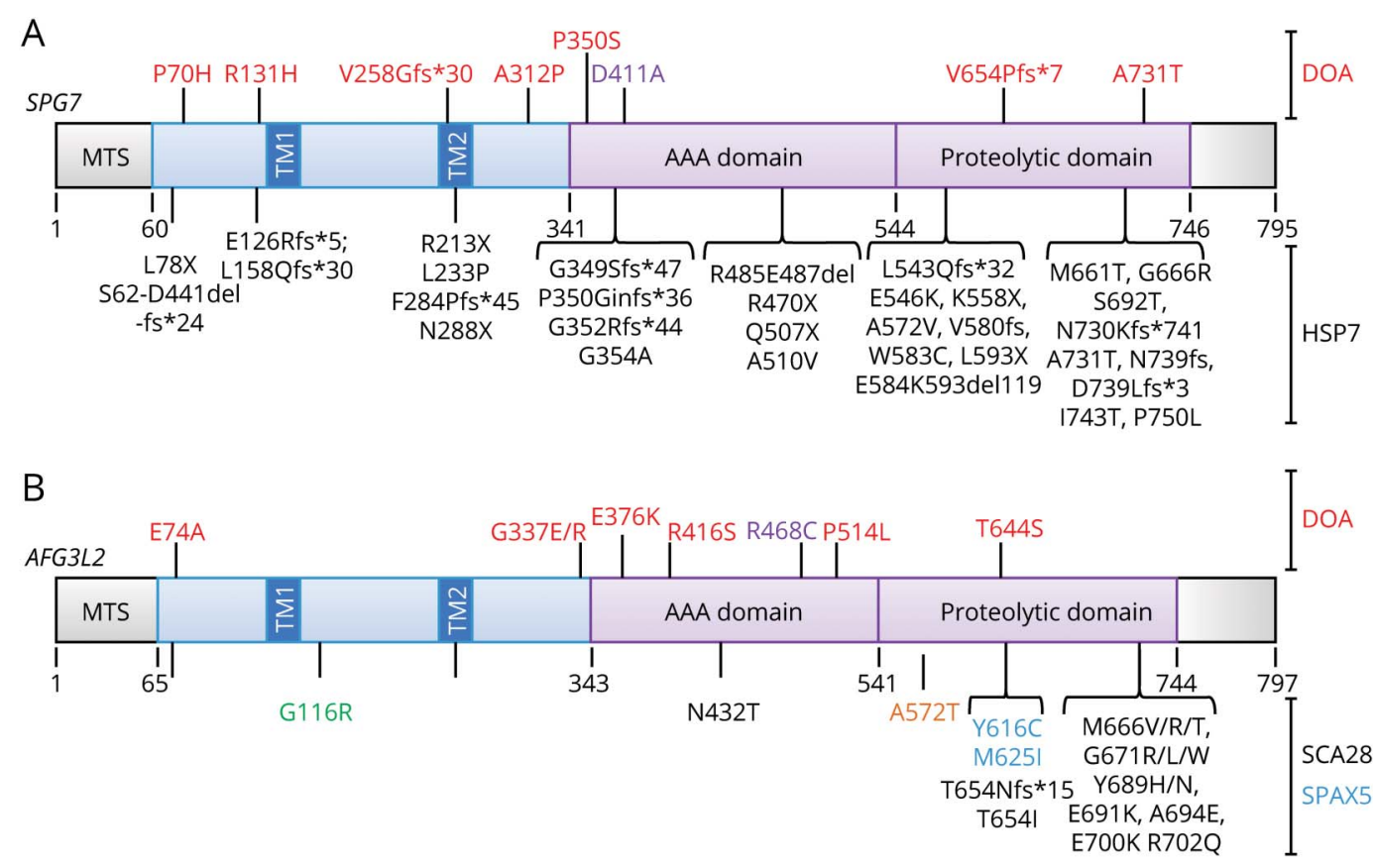

(A): Structure and domains of the SPG7 protein with the amino acid changes associated with DOA (top) and HSP7 (bottom); red, mutations identified in this study; purple, a DOA mutation previously reported; and black: HSP7 published mutations. (B): Structure and domains of the AFG3L2 protein with the amino acid changes associated with DOA (top) and to other diseases (bottom); red, mutations identified in this study; purple, a previously reported DOA mutation; black, published mutations responsible for SCA28; blue, published mutations responsible for recessive spastic ataxia SPAX5; in green, myoclonus and pyramidal signs; and in orange, microcephaly, early onset seizures, spasticity, and basal ganglia atrophy. DOA = dominant optic atrophy; SCA28 = spinocerebellar ataxia; SPAX5 = spastic ataxia-neuropathy syndrome.

mutation carriers to legal blindness and, in some of them, to a more severe syndromic manifestation with sensorineural deafness. $^{21}$

It is intriguing that SPG7 mutations can behave both dominantly and recessively with variable tissue specificity. Of interest, in a previous work reporting novel SPG7 mutations, 10 affected individuals underwent an ophthalmologic examination and all of them had evidence of a mild optic neuropathy with bilateral optic disc pallor and thinning of the peripapillary RNFL on OCT imaging. ${ }^{12}$ Conversely, the neurologic examination by the same team of the first-identified SPG7-related DOA family did not evidence any gait or walking difficulties in mutation carriers. In addition, the SPG7 variants that we identified in individuals with DOA are interspersed with the recessive variants resulting in HSP7, and in both diseases frameshift variants are contributing to the pathophysiologic mechanism. Altogether, these data suggest a clinical overlap related to SPG7 mutations between DOA on one end and HSP7 on the other end and all possible mixed phenotype inbetween. These observations should prompt to perform a systematic neuroophthalmological examination of individuals with HSP7 and their heterozygous parents. Similarly, DOA individuals with a SPG7 variant should have a neurologic follow-up, particularly older than the age of 40 years, to evaluate the eventual occurrence of spasticity and also cognitive impairment, epilepsy, and cerebellar atrophy.
Dominant mutations in $A F G 3 L 2$ were initially found in individuals affected with SCA28 and do localize in exons 15 and 16 , in addition to one in exon $10 .^{22}$ Recessive consanguineous $A F G 3 L 2$ mutations in exon 15 were also identified in a spastic ataxia-neuropathy syndrome ${ }^{23}$ (SPAX5), whereas 2 additional dominant AFG3L2 variants were identified in an individual affected with myoclonus and pyramidal signs ${ }^{24}$ and a recessive mutation in another family affected with microcephaly, early onset seizures, spasticity, and basal ganglia atrophy. ${ }^{25}$ Of interest, the 8 missense $A F G 3 L 2$ variants that we identified in individuals with DOA are involving other domains than those identified earlier, thus explaining the absence of clinical overlap between all the symptoms previously described for AFG3L2 mutations and the optic atrophy found in this study. This is reinforced by the normality of the brain MRI and the absence of ataxia in AFG3L2-related patients with DOA. Nevertheless, we suggest that the ophthalmologic follow-up of these individuals should be accompanied by a neurologic examination to eventually diagnose early manifestations of cerebellar ataxia or any other clinical symptoms.

The 2 m-AAA proteases encoded by SPG7 and AFG3L2 genes have been described as promoting OPA1 cleavage to its short profission isoforms. ${ }^{19}$ This activity is under the control of OMA1 and YME1L proteases that directly process 
the cleavage of OPA1. ${ }^{26}$ Our data suggest that this mechanism might be affected by the dominant variants in both genes, although at different levels, depending on the mutated gene. Indeed, AFG3L2 forms both homopolymers and heteropolymers with SPG7; therefore, pathogenic variants should affect the activity of both types of polymers. Conversely, SPG7 can only form heteropolymers with AFG3L2, but not homopolymers, implying that pathogenic variants should only affect the activity of the AFG3L2-SPG7 heteropolymers. This might explain the relatively mild visual deficits in individuals with SPG7 variants, contrasting with the more severe visual loss observed in individuals with AFG3L2 variants and the syndromic DOA plus phenotype found in a patient harboring concurrent mutations in both genes. It further questions the possible specificity of these mutations for the regulation of $O P A 1$ processing. In this respect, mitochondrial dynamic might be affected by the other SPG7 mutations but overwhelmed by the severe HSP7 phenotype, whereas it is apparently not affected by the AFG3L2 variants involved in SCA28. This reflect the fact that no optic atrophy has been yet reported in the mouse models harboring Spg7 or Afg3l2 mutations.

Thus, we provide compelling evidence that heterozygous SPG7 and AFG3L2 mutations should be considered in the cases of isolated DOA, more so when already found to be $O P A 1$-negative. Our findings stress the central role mediated by $\mathrm{m}$-AAA proteases in the regulation of mitochondrial dynamics and how dysfunction of these pathways compromise the RGC integrity and survival, resulting in optic neuropathy.

\section{Acknowledgment}

The authors are indebted to Dr. Vittoria Petruzzella, Silvana Guerriero, Anna Maria De Negri, and Michele Carbonelli for clinical investigations and thank Dr. Menetou for stimulating critical discussions.

\section{Study funding}

The authors are indebted for the financial support to the Université d'Angers, CHU d'Angers, the Région Pays de la Loire, Angers Loire Métropole, the Fondation Maladies Rares, the Fondation VISIO, Kjer-France, Ouvrir Les Yeux, Retina France, UNADEV, Fondation de France, and Association Française contre les Myopathies.

\section{Disclosure}

P. Yu-Wai-Man is supported by a Clinician Scientist Fellowship Award (G1002570) from the Medical Research Council (UK) and also receives funding from Fight for Sight (UK), the Isaac Newton Trust (UK), the UK National Institute of Health Research (NIHR) as part of the Rare Diseases Translational Research Collaboration, and the NIHR Biomedical Research Centre based at Moorfields Eye Hospital NHS Foundation Trust and UCL Institute of Ophthalmology. L. Caporali is supported by the Grant GR-2016-
02361449 and VC by the "Ricerca Corrente" funding, both from the Italian Ministry of Health. The views expressed are those of the author(s) and not necessarily those of the NHS, the NIHR, or the Department of Health. M. Charif, A. Chevrollier, N. Gueguen, C. Bris, D. Goudenège, V. Desquiret-Dumas, S. Leruez, E. Colin, A. Meunier, C. Vignal, V. Smirnov, S. Defoort-Dhellemmes, I. Drumare Bouvet, C. Goizet, M. Votruba, N. Jurkute, P. Yu-Wai-Man, F. Tagliavini, L. Caporali, C. La Morgia, V. Carelli, V. Procaccio, X. Zanlonghi, I. Meunier, P. Reynier, D. Bonneau, P. AmatiBonneau, and G. Lenaers report no disclosures relevant to the manuscript. Go to Neurology.org/NG for full disclosures.

\section{Publication history}

Received by Neurology: Genetics November 22, 2019. Accepted in final form April 6, 2020.

Appendix Authors

\begin{tabular}{|c|c|c|}
\hline Name & Location & Contribution \\
\hline $\begin{array}{l}\text { Majida Charif, } \\
\text { PhD }\end{array}$ & $\begin{array}{l}\text { University of } \\
\text { Angers, France }\end{array}$ & $\begin{array}{l}\text { Acquisition and analysis of } \\
\text { the data and drafting } \\
\text { a significant portion of } \\
\text { the manuscript and } \\
\text { figures }\end{array}$ \\
\hline $\begin{array}{l}\text { Arnaud } \\
\text { Chevrollier, } \\
\text { PhD }\end{array}$ & $\begin{array}{l}\text { University of } \\
\text { Angers, France }\end{array}$ & $\begin{array}{l}\text { Acquisition and analysis of } \\
\text { the data }\end{array}$ \\
\hline $\begin{array}{l}\text { Naïg Gueguen, } \\
\text { PhD }\end{array}$ & $\begin{array}{l}\text { University and } \\
\text { Hospital of Angers, } \\
\text { France }\end{array}$ & $\begin{array}{l}\text { Acquisition and analysis of } \\
\text { the data }\end{array}$ \\
\hline Céline Bris, PhD & $\begin{array}{l}\text { University and } \\
\text { Hospital of Angers, } \\
\text { France }\end{array}$ & $\begin{array}{l}\text { Acquisition and analysis of } \\
\text { the data }\end{array}$ \\
\hline $\begin{array}{l}\text { David } \\
\text { Goudenège, PhD }\end{array}$ & $\begin{array}{l}\text { University and } \\
\text { Hospital of } \\
\text { Angers, } \\
\text { France }\end{array}$ & $\begin{array}{l}\text { Acquisition and analysis of } \\
\text { the data }\end{array}$ \\
\hline $\begin{array}{l}\text { Valérie } \\
\text { Desquiret- } \\
\text { Dumas, PhD }\end{array}$ & $\begin{array}{l}\text { University and } \\
\text { Hospital of Angers, } \\
\text { France }\end{array}$ & $\begin{array}{l}\text { Acquisition and analysis of } \\
\text { the data }\end{array}$ \\
\hline $\begin{array}{l}\text { Stéphanie } \\
\text { Leruez, MD }\end{array}$ & $\begin{array}{l}\text { University and } \\
\text { Hospital of Angers, } \\
\text { France }\end{array}$ & $\begin{array}{l}\text { Clinical investigation and } \\
\text { phenotyping }\end{array}$ \\
\hline $\begin{array}{l}\text { Estelle Colin, MD, } \\
\text { PhD }\end{array}$ & $\begin{array}{l}\text { University and } \\
\text { Hospital of Angers, } \\
\text { France }\end{array}$ & $\begin{array}{l}\text { Clinical investigation and } \\
\text { phenotyping }\end{array}$ \\
\hline $\begin{array}{l}\text { Audrey Meunier, } \\
\text { MD }\end{array}$ & $\begin{array}{l}\text { University and } \\
\text { Hospital of Brussels, } \\
\text { Belgium }\end{array}$ & $\begin{array}{l}\text { Clinical investigation and } \\
\text { phenotyping }\end{array}$ \\
\hline $\begin{array}{l}\text { Catherine Vignal, } \\
\text { MD, PhD }\end{array}$ & $\begin{array}{l}\text { Rothschild } \\
\text { Ophthalmologic } \\
\text { Foundation, Paris, } \\
\text { France }\end{array}$ & $\begin{array}{l}\text { Clinical investigation and } \\
\text { phenotyping }\end{array}$ \\
\hline $\begin{array}{l}\text { Vasily Smirnov, } \\
\text { MD }\end{array}$ & $\begin{array}{l}\text { University and } \\
\text { Hospital of Lille, } \\
\text { France }\end{array}$ & $\begin{array}{l}\text { Clinical investigation and } \\
\text { phenotyping }\end{array}$ \\
\hline
\end{tabular}


Appendix (continued)

\begin{tabular}{|c|c|c|}
\hline Name & Location & Contribution \\
\hline $\begin{array}{l}\text { Sabine Defoort- } \\
\text { Dhellemmes, MD }\end{array}$ & $\begin{array}{l}\text { University and } \\
\text { Hospital of Lille, } \\
\text { France }\end{array}$ & $\begin{array}{l}\text { Clinical investigation and } \\
\text { phenotyping }\end{array}$ \\
\hline $\begin{array}{l}\text { Isabelle Drumare } \\
\text { Bouvet, MD }\end{array}$ & $\begin{array}{l}\text { University and } \\
\text { Hospital of Lille, } \\
\text { France }\end{array}$ & $\begin{array}{l}\text { Clinical investigation and } \\
\text { phenotyping }\end{array}$ \\
\hline $\begin{array}{l}\text { Cyril Goizet, MD, } \\
\text { PhD, }\end{array}$ & $\begin{array}{l}\text { University and } \\
\text { Hospital of } \\
\text { Bordeaux, France }\end{array}$ & $\begin{array}{l}\text { Clinical investigation and } \\
\text { phenotyping }\end{array}$ \\
\hline $\begin{array}{l}\text { Marcela Votruba, } \\
\text { MD, PhD }\end{array}$ & $\begin{array}{l}\text { University and } \\
\text { Hospital of Cardiff, } \\
\text { UK }\end{array}$ & $\begin{array}{l}\text { Clinical investigation and } \\
\text { phenotyping }\end{array}$ \\
\hline $\begin{array}{l}\text { Neringa Jurkute, } \\
\text { MD, PhD }\end{array}$ & $\begin{array}{l}\text { University College of } \\
\text { London, UK }\end{array}$ & $\begin{array}{l}\text { Clinical investigation and } \\
\text { phenotyping }\end{array}$ \\
\hline $\begin{array}{l}\text { Patrick Yu-Wai- } \\
\text { Man, MD, PhD }\end{array}$ & $\begin{array}{l}\text { University College of } \\
\text { London, UK }\end{array}$ & $\begin{array}{l}\text { Clinical investigation and } \\
\text { phenotyping }\end{array}$ \\
\hline $\begin{array}{l}\text { Francesca } \\
\text { Tagliavini, PhD }\end{array}$ & $\begin{array}{l}\text { University of } \\
\text { Bologna, Italy }\end{array}$ & $\begin{array}{l}\text { Acquisition and analysis of } \\
\text { the data }\end{array}$ \\
\hline $\begin{array}{l}\text { Leonardo } \\
\text { Caporali, PhD }\end{array}$ & $\begin{array}{l}\text { University of } \\
\text { Bologna, Italy }\end{array}$ & $\begin{array}{l}\text { Acquisition and analysis of } \\
\text { the data }\end{array}$ \\
\hline $\begin{array}{l}\text { Chiara La } \\
\text { Morgia, MD, PhD }\end{array}$ & $\begin{array}{l}\text { University and } \\
\text { Hospital of Bologna, } \\
\text { Italy }\end{array}$ & $\begin{array}{l}\text { Clinical investigation and } \\
\text { phenotyping }\end{array}$ \\
\hline $\begin{array}{l}\text { Valerio Carelli, } \\
\text { MD, PhD }\end{array}$ & $\begin{array}{l}\text { University and } \\
\text { Hospital of Bologna, } \\
\text { Italy }\end{array}$ & $\begin{array}{l}\text { Clinical investigation and } \\
\text { phenotyping }\end{array}$ \\
\hline $\begin{array}{l}\text { Vincent } \\
\text { Procaccio, MD, } \\
\text { PhD }\end{array}$ & $\begin{array}{l}\text { University and } \\
\text { Hospital of Angers, } \\
\text { France }\end{array}$ & $\begin{array}{l}\text { Clinical investigation and } \\
\text { phenotyping }\end{array}$ \\
\hline $\begin{array}{l}\text { Xavier } \\
\text { Zanlonghi, MD, }\end{array}$ & $\begin{array}{l}\text { Clinique Jules Verne, } \\
\text { Nantes, France }\end{array}$ & $\begin{array}{l}\text { Clinical investigation and } \\
\text { phenotyping }\end{array}$ \\
\hline $\begin{array}{l}\text { Isabelle Meunier, } \\
\text { MD, PhD }\end{array}$ & $\begin{array}{l}\text { Hospital of } \\
\text { Montpellier, France }\end{array}$ & $\begin{array}{l}\text { Clinical investigation and } \\
\text { phenotyping }\end{array}$ \\
\hline $\begin{array}{l}\text { Pascal Reynier, } \\
\text { MD, PhD }\end{array}$ & $\begin{array}{l}\text { University and } \\
\text { Hospital of Angers, } \\
\text { France }\end{array}$ & $\begin{array}{l}\text { Clinical investigation and } \\
\text { phenotyping; Acquisition } \\
\text { and analysis of the data }\end{array}$ \\
\hline $\begin{array}{l}\text { Dominique } \\
\text { Bonneau, MD, } \\
\text { PhD, }\end{array}$ & $\begin{array}{l}\text { University and } \\
\text { Hospital of Angers, } \\
\text { France }\end{array}$ & $\begin{array}{l}\text { Clinical investigation and } \\
\text { phenotyping and revised the } \\
\text { manuscript for intellectual } \\
\text { content }\end{array}$ \\
\hline $\begin{array}{l}\text { Patrizia Amati- } \\
\text { Bonneau, MD, } \\
\text { PhD }\end{array}$ & $\begin{array}{l}\text { University and } \\
\text { Hospital of Angers, } \\
\text { France }\end{array}$ & $\begin{array}{l}\text { Conception and design of } \\
\text { the study and acquisition } \\
\text { and analysis of the data }\end{array}$ \\
\hline $\begin{array}{l}\text { Guy Lenaers, } \\
\text { PhD }\end{array}$ & $\begin{array}{l}\text { University and } \\
\text { Hospital of Angers, } \\
\text { France }\end{array}$ & $\begin{array}{l}\text { Conception and design of } \\
\text { the study and drafting } \\
\text { a significant portion of the } \\
\text { manuscript and figures }\end{array}$ \\
\hline
\end{tabular}

\section{References}

1. Lenaers G, Hamel C, Delettre C, et al. Dominant optic atrophy. Orphanet J Rare Dis 2012;7:46.

2. Yu-Wai-Man P, Chinnery PF. Dominant optic atrophy: novel OPAl mutations and revised prevalence estimates. Ophthalmology 2013;120:1712.

3. Alexander C, Votruba M, Pesch UE, et al. OPA1, encoding a dynamin-related GTPase, is mutated in autosomal dominant optic atrophy linked to chromosome 3q28. Nat Genet 2000;26:211-215.

4. Delettre C, Lenaers G, Griffoin JM, et al. Nuclear gene OPA1, encoding a mitochondrial dynamin-related protein, is mutated in dominant optic atrophy. Nat Genet 2000;26:207-210.

5. Ferré M, Caignard A, Milea D, et al. Improved locus-specific database for OPAl mutations allows inclusion of advanced clinical data. Hum Mutat 2015;36:20-25.

6. Le Roux B, Lenaers G, Zanlonghi X, et al. OPA1: 516 unique variants and 831 patients registered in an updated centralized Variome database. Orphanet J Rare Dis 2019;14: 214.

7. Olichon A, Landes T, Arnauné-Pelloquin L, et al. Effects of OPA1 mutations on mitochondrial morphology and apoptosis: relevance to ADOA pathogenesis. J Cell Physiol 2007;211:423-430.

8. Bertholet AM, Delerue T, Millet AM, et al. Mitochondrial fusion/fission dynamics in neurodegeneration and neuronal plasticity. Neurobiol Dis 2016;90:3-19.

9. Gerber S, Charif M, Chevrollier A, et al. Mutations in DNM1L, as in OPA1, result in dominant optic atrophy despite opposite effects on mitochondrial fusion and fission. Brain 2017; 140:2586-2596.

10. Rouzier C, Bannwarth S, Chaussenot A, et al. The MFN2 gene is responsible for mitochondrial DNA instability and optic atrophy 'plus' phenotype. Brain 2012;135: 23-34.

11. Reynier P, Amati-Bonneau P, Verny C, et al. OPA3 gene mutations responsible for autosomal dominant optic atrophy and cataract. J Med Genet 2004;41:e110.

12. Klebe S, Depienne C, Gerber S, et al. Spastic paraplegia gene 7 in patients with spasticity and/or optic neuropathy. Brain 2012;135:2980-2993.

13. Charif M, Roubertie A, Salime S, et al. A novel mutation of AFG3L2 might cause dominant optic atrophy in patients with mild intellectual disability. Front Genet 2015; 6:311.

14. Colavito D, Maritan V, Suppiej A, et al. Non-syndromic isolated dominant optic atrophy caused by the p.R468C mutation in the AFG3 like matrix AAA peptidase subunit 2 gene. Biomed Rep 2017;7:451-454.

15. Casari G, De Fusco M, Ciarmatori $S$, et al. Spastic paraplegia and OXPHOS impairment caused by mutations in paraplegin, a nuclear-encoded mitochondrial metalloprotease. Cell 1998;93:973-983.

16. Di Bella D, Lazzaro F, Brusco A, et al. Mutations in the mitochondrial protease gene AFG3L2 cause dominant hereditary ataxia SCA28. Nat Genet 2010;42:313-321.

17. Magri S, Fracasso V, Plumari M, et al. Concurrent AFG3L2 and SPG7 mutations associated with syndromic parkinsonism and optic atrophy with aberrant OPAl processing and mitochondrial network fragmentation. Hum Mutat 2018;39: 2060-2071

18. Carelli V, Musumeci O, Caporali L, et al. Syndromic parkinsonism and dementia associated with OPA1 missense mutations. Ann Neurol 2015; 78: 21-38.

19. Ehses S, Raschke I, Mancuso G, et al. Regulation of OPAl processing and mitochondrial fusion by m-AAA protease isoenzymes and OMA1. J Cell Biol 2009; 187 1023-1036.

20. Felhi R, Sfaihi L, Charif M, et al. Next generation sequencing in family with MNGIE syndrome associated to optic atrophy: novel homozygous POLG mutation in the C-terminal sub-domain leading to mtDNA depletion. Clin Chim Acta 2019;488 104-110.

21. Yu-Wai-Man P, Griffiths PG, Gorman GS, et al. Multi-system neurological disease is common in patients with OPA1 mutations. Brain 2010; 133: 771-786.

22. Cagnoli C, Stevanin G, Brussino A, et al. Missense mutations in the AFG3L2 proteolytic domain account for $\sim 1.5 \%$ of European autosomal dominant cerebellar ataxias. Hum Mutat 2010;31:1117-1124.

23. Pierson TM, Adams D, Bonn F, et al. Whole-exome sequencing identifies homozygous AFG3L2 mutations in a spastic ataxia-neuropathy syndrome linked to mitochondrial m-AAA proteases. PLoS Genet 2011;7:e1002325.

24. Mancini C, Orsi L, Guo Y, et al. An atypical form of AOA2 with myoclonus associated with mutations in SETX and AFG3L2. BMC Med Genet 2015;16:16.

25. Eskandrani A, AlHashem A, Ali ES, et al. Recessive AFG3L2 mutation causes progressive microcephaly, early onset seizures, spasticity, and basal ganglia involvement. Pediatr Neurol 2017;71:24-28.

26. Anand R, Wai T, Baker MJ, et al. The i-AAA protease YME1L and OMAl cleave OPA1 to balance mitochondrial fusion and fission. J Cell Biol 2014;204:919-929. 


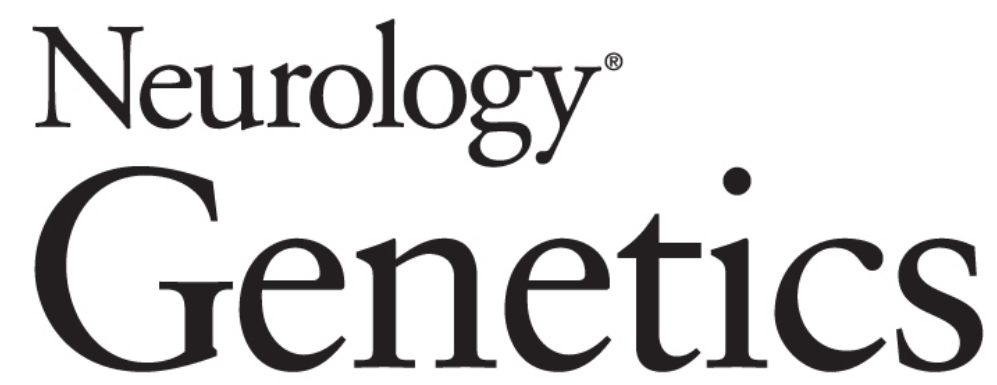

Mutations in the m-AAA proteases AFG3L2 and SPG7 are causing isolated dominant optic atrophy

Majida Charif, Arnaud Chevrollier, Naïg Gueguen, et al.

Neurol Genet 2020;6;

DOI 10.1212/NXG.0000000000000428

This information is current as of May 20, 2020

Neurol Genet is an official journal of the American Academy of Neurology. Published since April 2015, it is an open-access, online-only, continuous publication journal. Copyright Copyright ( 2020 The Author(s).

Published by Wolters Kluwer Health, Inc. on behalf of the American Academy of Neurology.. All rights reserved. Online ISSN: 2376-7839.

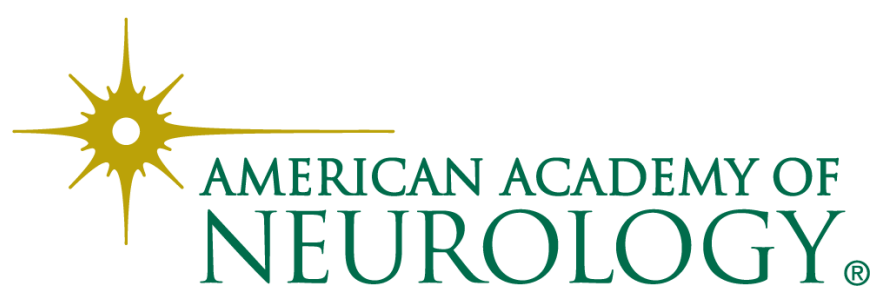




\section{Updated Information \& Services}

References

Citations

Subspecialty Collections

Permissions \& Licensing

Reprints including high resolution figures, can be found at: http://ng.neurology.org/content/6/3/e428.full.html

This article cites 26 articles, 3 of which you can access for free at: http://ng.neurology.org/content/6/3/e428.full.html\#\#ref-list-1

This article has been cited by 1 HighWire-hosted articles: http://ng.neurology.org/content/6/3/e428.full.html\#\#otherarticles

This article, along with others on similar topics, appears in the following collection(s):

\section{Mitochondrial disorders}

http://ng.neurology.org//cgi/collection/mitochondrial_disorders Optic nerve

http://ng.neurology.org//cgi/collection/optic_nerve

Optic neuritis; see Neuro-ophthalmology/Optic Nerve

http://ng.neurology.org//cgi/collection/optic_neuritis

Spinocerebellar ataxia

http://ng.neurology.org//cgi/collection/spinocerebellar_ataxia

Visual loss

http://ng.neurology.org//cgi/collection/visual_loss

Information about reproducing this article in parts (figures,tables) or in its entirety can be found online at:

http://ng.neurology.org/misc/about.xhtml\#permissions

Information about ordering reprints can be found online:

http://ng.neurology.org/misc/addir.xhtml\#reprintsus

Neurol Genet is an official journal of the American Academy of Neurology. Published since April 2015, it is an open-access, online-only, continuous publication journal. Copyright Copyright ( 2020 The Author(s). Published by Wolters Kluwer Health, Inc. on behalf of the American Academy of Neurology.. All rights reserved. Online ISSN: 2376-7839.

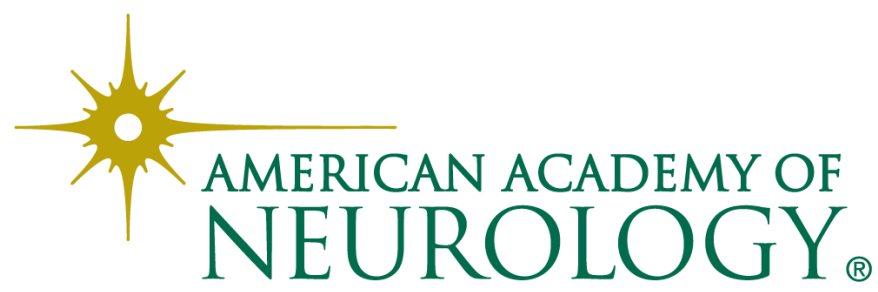

